\title{
Entrepreneurship, Subjectivism, and the Resource-based View Towards a New Synthesis
}

Foss, Nicolai J.; Klein, Peter G.; Kor, Yasemin Y.; Mahoney, Joseph T.

Document Version

Final published version

Publication date:

2006

\section{License \\ CC BY-NC-ND}

Citation for published version (APA):

Foss, N. J., Klein, P. G., Kor, Y. Y., \& Mahoney, J. T. (2006). Entrepreneurship, Subjectivism, and the Resourcebased View: Towards a New Synthesis. Center for Strategic Management and Globalization. SMG Working Paper No. 18/2006

Link to publication in CBS Research Portal

\section{General rights}

Copyright and moral rights for the publications made accessible in the public portal are retained by the authors and/or other copyright owners and it is a condition of accessing publications that users recognise and abide by the legal requirements associated with these rights.

\section{Take down policy}

If you believe that this document breaches copyright please contact us (research.lib@cbs.dk) providing details, and we will remove access to the work immediately and investigate your claim. 
Entrepreneurship, Subjectivism, and the Resource-based view: Towards a new Synthesis

\author{
Nicolai J. Foss \\ Peter G. Klein \\ Yasemin Y. Kor \\ Joseph T. Mahoney
}

SMG WP 18/2006

November 2006 
SMG Working Paper No. 18/2006

November 2006

ISBN: 87-91815-36-3

Center for Strategic Management and Globalization Copenhagen Business School

Porcelænshaven 24

2000 Frederiksberg

Denmark

www.cbs.dk/smg 


\title{
ENTREPRENEURSHIP, SUBJECTIVISM, AND THE RESOURCE- BASED VIEW: TOWARDS A NEW SYNTHESIS
}

\author{
Nicolai J. Foss \\ Copenhagen Business School \\ Yasemin Y. Kor \\ University of Delaware
}

\author{
Peter G. Klein \\ University of Missouri \\ Joseph T. Mahoney \\ University of Illinois at Urbana-Champaign
}

\begin{abstract}
This paper maintains that the consistent application of subjectivism helps to reconcile contemporary entrepreneurship theory with strategic management research in general, and the resource-based view in particular. The paper synthesizes theoretical insights from Austrian economics and Penrose's (1959) resources approach, arguing that entrepreneurship is inherently subjective and firm specific. This new synthesis describes how entrepreneurship is manifested in teams, and is driven by both heterogeneity of managerial mental models and shared team experiences.
\end{abstract}

Published: 2006

URL: http://www.business.uiuc.edu/Working Papers/papers/06-0121.pdf 


\title{
ENTREPRENEURSHIP, SUBJECTIVISM, AND THE RESOURCE- BASED VIEW: TOWARDS A NEW SYNTHESIS
}

\author{
Nicolai J. Foss \\ Center for Strategic Management and Globalization \\ Copenhagen Business School \\ Porcelainshaven 24 \\ 2000 Frederiksberg, Denmark \\ njf.smg@,cbs.dk \\ Peter G. Klein \\ Contracting and Organizations Research Institute \\ University of Missouri \\ 135 Mumford Hall \\ Columbia, MO 65211 USA \\ kleinp@missouri.edu \\ Yasemin Y. Kor \\ Department of Business Administration \\ University of Delaware \\ 214 Lerner Hall \\ Orchard Road \& Amstel Avenue \\ Newark, DE 19716-2710 \\ kory@udel.edu \\ Joseph T. Mahoney \\ Department of Business Administration \\ University of Illinois at Urbana-Champaign \\ 140C Wohlers Hall \\ 1206 South Sixth Street \\ Champaign, IL 61820 \\ josephm@uiuc.edu
}




\title{
ENTREPRENEURSHIP, SUBJECTIVISM, AND THE RESOURCE- BASED VIEW: TOWARDS A NEW SYNTHESIS
}

\begin{abstract}
This paper maintains that the consistent application of subjectivism helps to reconcile contemporary entrepreneurship theory with strategic management research in general, and the resource-based view in particular. The paper synthesizes theoretical insights from Austrian economics and Penrose's (1959) resources approach, arguing that entrepreneurship is inherently subjective and firm specific. This new synthesis describes how entrepreneurship is manifested in teams, and is driven by both heterogeneity of managerial mental models and shared team experiences.
\end{abstract}




\section{INTRODUCTION}

It has long been recognized in the research literature that entrepreneurship is the core of the dynamics of capitalism (Baumol, 1993) and the entrepreneur is "the driving force of the whole market system" (Mises, 1949: 249). More recently, management scholars have begun to recognize the value of incorporating entrepreneurship into strategic management research (e.g., Alvarez \& Barney, 2004; Hitt, Ireland, Camp \& Sexton, 2001). However, it is not clear how such a link is best established. The current paper maintains that the consistent application of subjectivism reconciles contemporary entrepreneurship theory with strategic management research in general, and the resource-based view in particular. ${ }^{1}$

In an oft-cited passage the Nobel Prize-winning Austrian economist F. A. Hayek claimed that all major advances in economics over the preceding hundred years had resulted from the “consistent application of subjectivism” (1955: 31). By subjectivism Hayek (1955) meant first, that individuals hold different preferences, knowledge, and expectations, and second, that explanations of individual and social action must begin with the mental states of the relevant individuals and must take into account the relevant differences in mental states. O'Driscoll and Rizzo submit that: "On the most general level, subjectivism refers to the pre-supposition that the contents of the human mind, and hence decision-making, are not rigidly determined by external events. Subjectivism makes room for the creativity and autonomy of individual choice"

\footnotetext{
${ }^{1}$ The current paper defines the "resource-based view" to include: (i) the resources approach (Barney, 1991; Peteraf, 1993; Rumelt, 1987; Wernerfelt, 1984); (ii) commitment (Ghemawat, 1991); (iii) dynamic capabilities (Dierickx \& Cool, 1989; Helfat, 1997; Rindova \& Kotha, 2001; Teece, Pisano \& Shuen, 1997) and (iv) the knowledge-based view (Grant, 1996; Kogut \& Zander, 1992; Spender, 1996, 2006). Alvarez and Busenitz observe that: "heterogeneity is a common attribute of both resource-based and entrepreneurship theory - although resource-based logic has tended to focus on heterogeneity of resources while entrepreneurship theory has tended to focus on heterogeneity in beliefs about the value of resources" (2001: 756). The concept of heterogeneity is usefully unpacked in terms of entrepreneurial cognition (Barr, Stimpert \& Huff, 1992), entrepreneurial discovery (Kirzner, 1997), changing market opportunities (Shane \& Venkatraman, 2000), and differential capabilities in the coordination of knowledge (Conner \& Prahalad, 1996).
} 
(O’Driscoll \& Rizzo, 1985: 1). Within economics, the Austrian School (e.g., Hayek, 1948; Menger, 1871; Mises, 1949) has been the most systematic exponent of subjectivism.

Despite its well-established foundations, explicit acknowledgment of subjectivism is rare in the strategic management literature, the resource-based view included. And yet, one of the founding contributions to the resource-based view, Penrose's (1959) The Theory of the Growth of Firm, is an exemplar of a subjectivist perspective applied to the study of resources. Penrose's subjectivist application of the resources approach is as an application of the subjectivist approach learned from Boulding (1956) and Machlup (1967). ${ }^{2}$ By elaborating Penrose's (1959) research contributions in this context, this paper aims to respond to recent calls for infusing the resourcebased view with entrepreneurship (Alvarez \& Barney, 2005; Kim \& Mahoney, 2006). We maintain that this infusion can be accomplished by consistent application of subjectivism, which leads to novel implications for entrepreneurship and resource-based research.

Our research focus not only helps to advance the theoretical understanding of the role of subjectivism in entrepreneurship, but it also helps us recognize an important gap in the research literature. The classic contributions to the theory of entrepreneurship from Richard Cantillon, Joseph Schumpeter, Frank Knight, Israel Kirzner and others, tend to portray entrepreneurial activity as an individual endeavor, consequently neglecting the possibility that entrepreneurial judgment and recognition of opportunities may be derived from social processes such as dynamic interactions among entrepreneurs in a team setting. While ultimately only individuals think, act, and choose, entrepreneurial judgment and discovery is influenced by context, such as the characteristics of the resources already under the entrepreneur's control and the composition

\footnotetext{
${ }^{2}$ Penrose's Theory of the Growth of the Firm (1959) was written at John Hopkins University and was highly influenced by Fritz Machlup. In turn, Machlup's dissertation advisor was the Austrian economist Ludwig von Mises, considered by most as the leader of the "third generation" of the Austrian School. Thus, it is not difficult to link the origins of resource-based view with entrepreneurship and Austrian subjectivism by closely examining Penrose's (1959) seminal book. Coming full circle recent research has re-discovered the connections between entrepreneurship and the resource-based view. We thank Professor Asli Arikan for this observation. For detailed evaluations of Penrose's (1959) contributions, see Mahoney and Pandian (1992), Foss (1998), Pitelis (2002), Kor and Mahoney (2004), and Mahoney (2005).
} 
and team dynamics of the entrepreneurial management team. Thus, this paper outlines a subjectivist theory of team entrepreneurship that not only gives close attention to the subjectivist nature of individuals' creativity, knowledge, and expectations, but also emphasizes the interactions among team members' heterogeneous mental models. As we identify the building blocks of the foundation of team entrepreneurship, we also consider what factors enable or constrain creation and discovery in social settings.

We begin by clarifying the central construct of subjectivism, drawing on the Austrian School of economics. Focusing on the differences between the notions of entrepreneurial alertness and entrepreneurial judgment, we show how subjectivism underpins the distinctively Austrian approach to entrepreneurship. We also demonstrate that subjectivism and the Austrian approach are in many ways remarkably close to those held by Penrose (1959), who brings to our attention the importance of management (team) cognition and resource specificity in firm-level growth. Based on these key insights, we present a subjectivist approach to entrepreneurship in which the team, rather than the individual entrepreneur, is the unit of analysis, and in which the subjective dimensions of the team's capital or resources is the key determinant of entrepreneurial activity. Through a synthesis of key ideas taken from Austrian economics and Penrose's (1959) resources approach, we develop the theoretical insight that entrepreneurship is inherently both subjective and firm specific. Finally, we discuss the implications of subjectivism and team entrepreneurship for contemporary practice and research in entrepreneurship and strategy.

\section{SUBJECTIVISM, ENTREPRENEURSHIP, AND RESOURCE HETEROGENEITY}

\section{Subjectivism in the Austrian Tradition}

The Austrian tradition is increasingly well known in the management research literature for its contributions to the theory of entrepreneurship and the complementary "market-process" explanation of economic activity (e.g., Hill \& Deeds, 1996; Jacobson 1992; Roberts \& 
Eisenhardt, 2003; Shane, 2003). However, other ideas in the Austrian tradition such as the timestructure of capital (Hayek, 1941) and capital heterogeneity (Lachmann, 1956) have received little research attention. Similarly, the strategic management literature has yet to explore the implications of subjectivism, which is central to the current paper.

Subjectivism holds that individuals have different preferences, knowledge and expectations, and that one cannot understand an individual's behavior without reference to that individual's subjective beliefs. Consider preferences, for example. Because preferences are unobservable, it is not possible to comment on individuals' preferences apart from their actions. The statement that voluntary exchange is mutually beneficial (ex ante) is an application of subjectivism. The fact that each participant forgoes one good or service in exchange for another shows that the good or service acquired ranks higher on the individual's value scale than the good or service foregone. Similarly, the significance of a particular capital asset to the production of a consumer good is determined, subjectively, by the entrepreneur, as expressed in a willingness to pay for the services of that asset, and not by some objective, technological characteristics of the asset (Kirzner, 1966). More generally, (opportunity) cost itself is ultimately a subjective concept (Buchanan, 1969).

Observable outcomes are an unintended consequence of the interaction of multiple actions that have been taken on the basis of subjectively held preferences, knowledge and expectations. Subjectivism maintains that any explanation of human action and interaction must not only start from the mental states of the relevant individuals, but also take into account the relevant differences in these mental states (Mises, 1949; Machlup, 1978). Hayek notes that competitive dynamics involves "a process of the formation of opinion ... a process which involves a continuous change in the data and whose significance must therefore be completely missed by any theory which treats these data as constant" (1948: 94). Entrepreneurs can be usefully described as exploring and taking advantage of economically valuable opportunities, 
which lead to market dynamics that drive an economic system (McGrath, 2001; Thornhill \& Amit, 2001). Yet, such a perspective is only intelligible if subjectivism is the starting point.

The subjectivism of knowledge. An important step in the development of subjectivism is the subjectivism of knowledge, that is, the explicit recognition in theorizing that not only is there subjectivism of preferences, but also that individuals hold different knowledge that may be private, tacit and subject to change (Polanyi, 1962). As Hayek (1945) pointed out, there is a division of knowledge in society that matches the division of labor. These ideas, however, go beyond contemporary (e.g., agency-theoretic) emphasis on asymmetric information (cf. Kirzner, 1997). Lachmann (1986) maintains that information received needs to be interpreted with regards to its possible uses in practice, and that the act of interpretation is a genuine problemsolving activity. The subjectivism of knowledge means that information relevant to economic activity is inherently subjective.

The subjectivism of expectations. Often seen as a natural outgrowth of the subjectivism of knowledge, this step is based on an indeterministic ontology (Lachmann, 1977; Shackle, 1972). This subjectivist perspective on entrepreneurship emphasizes the indeterministic, evolutionary nature of dynamic capabilities and entrepreneurial activities (O'Driscoll \& Rizzo, 1985). One form of indeterminism can be found in Nelson and Winter (1982), who maintain that search for superior heuristics is partly deterministic and partly stochastic, and which is captured in their use of Markov processes. The Austrian tradition emphasizes the purposeful, goaloriented nature of human action, however, meaning that stochastic processes cannot fully capture the essence of entrepreneurial behavior. Kirzner's concept of entrepreneurial discovery represents a mild form of indeterminism, one that is still anchored in the concept of purposeful human action. "The notion of discovery, midway between that of the deliberately produced information in standard search theory, and that of sheer windfall gain generated by pure chance is central to the Austrian approach" (1997: 72). A stronger form of indeterminism emphasizes 
that the future is not merely unknown, but unknowable. That said, however, it is emphasized here that: "the future is unknowable, but not unimaginable" (Lachmann, 1976: 53). Entrepreneurs must use "imagination" to interpret economic data and to anticipate future market conditions. Entrepreneurship is seen as human action that creatively formulates and solves new problems (Mises, 1949). Indeed, research literature from the Austrian School tradition has provided more specific treatments of the entrepreneurial function, which we turn to next.

\section{Subjectivism and Entrepreneurial Judgment}

The Austrian research literature emphasizes at least two different concepts of entrepreneurship, one concept interpreting entrepreneurship as alertness (Kirzner, 1973), and another concept characterizing entrepreneurship as judgment (Knight, 1921). ${ }^{4}$ Since the first concept is perhaps best known in management (Ardichvili, Cardozo \& Ray, 2003; Busenitz, 1996; Sorensen \& Sorenson, 2003; Venkatraman, 1997), we briefly consider this concept first. However, as we argue below, the alertness approach to entrepreneurship is not sufficient for bridging the entrepreneurship and strategic management research literatures.

Entrepreneurship as alertness. While present in Cantillon's (1755) notion of entrepreneurship, this concept has been elaborated most fully by Kirzner (1973), which follows Hayek (1968) in describing competition as a discovery process. Rumelt, building on the concept of entrepreneurial discovery from the resource-based view, states that: "The two basic kinds of entrepreneurial discovery concern the value of resource combinations and the pattern of demand" (1987: 144). The source of entrepreneurial profit is superior foresight - the discovery of something (e.g., new products, new resource combinations, new cost-saving technologies, superior anticipation of demand patterns) — that is unknown to other market participants. As

\footnotetext{
${ }^{4}$ Langlois (2007: 4) states that: "Kirzner is about discovery, about alertness to new opportunities; Knight is about evaluation, about the facility of judgment in economic organization; and Schumpeter is of course about exploitation, about the carrying out of new combinations and the creative destruction that often results."
} 
examples, an arbitrageur may discover a discrepancy in present prices to exploit for financial gain or an entrepreneur may be alert to a new product or superior production process and subsequently fills this market gap before others (Jacobson, 1992). Success, in this discoveryprocess view, comes from having some asymmetric knowledge or new insight.

Kirzner's (1973) concept of entrepreneurial alertness presupposes the subjectivism of knowledge. If all market participants were equally informed about market conditions, there would be no opportunities for entrepreneurial gain. However, Kirzner's (1973) approach has several drawbacks as a foundation for applied entrepreneurship research. First, the purpose of Kirzner (1973) in formulating a theory of entrepreneurship is primarily instrumental where the fundamental concept of entrepreneurial discovery signifies a "black-box" process by which profitable opportunities are seized, driving markets toward equilibrium. There is no theory of the processes by which entrepreneurial beliefs and expectations are formed, and what key factors affect the likelihood that particular entrepreneurial acts will be successful. For example, Kirzner (1973) does not analyze the effect of social processes such as the interactions among managers in a team on entrepreneurial activity (Penrose, 1959). Moreover, while only individuals are alert, alertness may be influenced by context, such as the composition of a top-management team (Kor, 2003). And finally, Kirzner's (1973) entrepreneurs do not own capital and thus are dissociated from the firm (Rothbard, 1962). Hence it is difficult to relate Kirzner's (1973) concept of entrepreneurship to firm-level strategies and to the resource-based view of the firm. This realized shortcoming brings us to the second concept of entrepreneurship, which we believe to be an important alternative view for future management research to more closely consider.

Entrepreneurship as judgment. An alternative view, also part of the Austrian tradition, describes entrepreneurship not as alertness to existing opportunities, but as the exercise of judgment regarding an uncertain future (Knight, 1921; Mises, 1949). This view traces its origins to the first systematic treatment of entrepreneurship, which conceives of entrepreneurship as 
judgmental decision-making under uncertainty (Cantillon, 1755). Judgment refers to decisionmaking when the range of possible future outcomes, let alone the likelihood of individual outcomes, is generally unknown — what Knight (1921) terms uncertainty, rather than mere probabilistic risk.

Judgment is distinct from boldness or imagination (Aldrich \& Wiedenmayer, 1993), innovation (Schumpeter, 1911, 1942), alertness (Kirzner, 1973), leadership (Witt, 1998), and other concepts of entrepreneurship that appear in the literature. ${ }^{5}$ Judgment must be exercised not only for strategic decisions, but also for tactical decisions, and for ongoing operations as well as for new ventures (Knight, 1921). The market test sorts out which entrepreneurial ideas are workable in the world of experience (Klein \& Klein, 2001).

Knight (1921) introduces judgment to connect firm-level economic profitability to the concept of uncertainty. Judgment refers to the process of entrepreneurs forming estimates of future events in which the relevant probability distributions are unknown. Knight (1921) makes an important conceptual distinction between "risk" and "uncertainty." A risky outcome is one in which the outcome itself is unknown, but is drawn from a known distribution. The concept of an uncertain outcome, by contrast, is one in which the distribution itself is unknown, even to the decision-maker. In this sense, Knightian uncertainty is consistent with the subjectivism of expectations (cf. Littlechild, 1986). Similarly, Schumpeter (1911: 85) emphasizes the concept of subjectivism of expectations and the related concept of differential skills of intuition by noting that: "intuition, the capacity of seeing things in a way which afterwards proves to be true, even though it cannot be established at the moment and of grasping the essential fact, discarding the unessential, even though one can give no account of the principles by which this is done."

\footnotetext{
${ }^{5}$ Whether Schumpeter $(1911,1942)$ belongs to the Austrian School of economics has often been debated. While Austrian by birth and a student of Eugen von Böhm-Bawerk (see, e.g., 1889), Schumpeter (1911, 1942) dissociated himself from Austrian economics, notably with respect to methodology, general equilibrium, and the theory of capital and interest. Still, Schumpeter's (1911, 1942) emphasis on the entrepreneur is closely related to the Austrian School of economics, and this body of work is too important to be ignored.
} 
Entrepreneurship represents a particular form of judgment that is non-contractible (Knight, 1921). Kirzner maintains that: "entrepreneurship reveals to the market what the market did not realize was available, or indeed, needed at all” (1979: 181). Casson takes a more Schumpeterian position stating that: "[t]he entrepreneur believes he is right, while everyone else is wrong. Thus, the essence of entrepreneurship is being different — being different because one has a different perception of the situation" (1982: 14). The implication is that there is no market for entrepreneurial judgment, and therefore exercising such judgment requires the person to start an entrepreneurial venture. Both entrepreneurial profitability and economic losses indicate that market participants have heterogeneous entrepreneurial judgments about future conditions.

In a highly simplified world that is posited to consist of homogeneous capital (including human capital) the entrepreneur's problem is simple and there is no basis for sustained economic rents (Foss \& Klein, 2005). However, capital is a set of heterogeneous capital goods, each of which possesses multiple attributes, (Lachmann, 1956), and effective judgment concerning the combination and deployment of capital goods is required. ${ }^{6}$ Resource uses are not data, but are created as entrepreneurs envision new ways of using the productive services of these resources for different goods and services (Penrose, 1959). As Alchian and Demsetz note: "efficient production with heterogeneous resources is a result not of having better resources, but in knowing more accurately the relative productive performances of those resources" (1972: 793). To use Penrose's (1959) terminology, resources potentially may yield many different kinds of services. What services these resources yield, and in which quantities and qualities is partly a matter of the entrepreneurial imagination, and partly a matter of the governance structures of the firm. These ideas, as we shall see, are central in Penrose's (1959) work to which we now turn.

\footnotetext{
6 The connections between subjectivism, judgment, capital heterogeneity, and the firm, and their implications for organizational economics are explored in Foss, Foss, Klein and Klein (2007). The current paper explores these connections and their implications for entrepreneurship and strategy research.
} 


\section{PENROSE (1959): AN AUSTRIAN VIEW OF STRATEGIC ENTREPRENEURSHIP}

\section{From Austrian Economics to Penrose's Resource-Based Approach}

While Penrose's (1959) The Theory of the Growth of the Firm is widely acknowledged as a pioneering work, the mainstream resource-based view has yet to appreciate fully the substance of this work (Foss, 2002). Similarly, with few exceptions (e.g., Foss, 1998; Loasby, 1991; Spender, 2006), the connections between Penrose (1959) and the Austrians are not fully appreciated, either within the Strategic Management field (where Austrian contributions are becoming increasingly well known; e.g., Jacobson, 1992; Roberts \& Eisenhardt, 2003) or within contemporary Austrian economics. We maintain here that Penrose's (1959) classic contribution to the resource-based view of the firm can be considered a continuation of the subjectivist tradition in (Austrian) economics. Penrose (1959) was primarily concerned with developing a theory of firm-level growth emphasizing the Austrian themes of cognition, learning, and adaptation. Penrose's (1959) emphasis on entrepreneurship, resource heterogeneity, and process significantly extends the Austrian analysis in terms of understanding heterogeneity based on the services that can be rendered from resources, and places this resources approach in a dynamic context in which management/resource interaction is highlighted.

Penrose (1959) advanced our understanding of a subjectivist theory of entrepreneurship. Penrose (1959) interprets resources/capital assets in distinctly subjectivist terms and emphasizes disequilibrium and path dependencies based on cumulative growth of collective knowledge in the context of a purposive firm. Moreover, Penrose (1959) applies key insights from the subjectivism of knowledge and expectations to managerial groups, rather than to individual decision-makers, and lays the foundations for a subjectivist theory of teams. This theory anchors the analysis of subjectivist expectations firmly in the experiences of the managerial team and in the resources the firm controls. In the following, we build on these key subjectivist points and develop the building blocks of a subjectivist theory of team entrepreneurship. 


\section{Subjectivism and the Heterogeneity of the Services of Resources}

Penrose's (1959) subjectivist approach to heterogeneity highlights that the productive services of resources must be discovered over time, as managers interact with resources and make subjective decisions about resource allocation, deployment, development, and maintenance (Kor \& Leblebici, 2005; Mosakowski, 1993). Future resource attributes are created as entrepreneurs envision new ways of using resources. Penrose emphasizes that: "it is never resources themselves that are the 'inputs' in the productive process, but only the services that the resource can render" (1959: 24-25). Extracting different services from similar (or even identical) resources makes firms not only heterogeneous but also defines their uniqueness.

The current paper introduces a broader definition of the entrepreneur, one that includes all individuals that are expected to play an important role in forming the subjective opportunity set of the firm. In other words, we suppress here the distinction between the entrepreneur and the manager (a distinction of key importance for Schumpeter, Knight, \& Kirzner.) Utilizing this more inclusive definition, entrepreneurship can occur at any level in the organization, which invites many scholars from different perspectives to contribute to the entrepreneurship research literature. However, consistent with Penrose's (1959) resources approach, the current paper gives close attention to the entrepreneurial services provided by the firm's managers, who play a central role in envisioning and cultivating heterogeneous services from the firm's resources. Serving in this central role, managers can have a strategic (i.e., long-lasting) impact on the organization's collective creativity, and learning capacity.

Thus, a firm's entrepreneurial growth process involves at least two major forms of heterogeneity. First, firms differ from one another in the resources they possess, and this resource heterogeneity influences strategy and helps explain sustained profitability differences among firms (Barney, 1991). However, the second form of heterogeneity, that is, heterogeneity of productive services from resources, is more concerned with how firms with similar resource 
bundles may still significantly differ in their entrepreneurial productivity. As Penrose explains, "it is the heterogeneity, and not the homogeneity, of the productive services available or potentially available from its resources that gives each firm its unique character" (1959: 75).

This second form of heterogeneity is at the heart of entrepreneurial creativity because it acknowledges the central role of management in converting resources to entrepreneurial services, where the subjective nature of entrepreneurial imagination results in unexpected variations in resource deployments and applications. As Penrose states: "the decision to search for opportunities in an enterprising decision requiring entrepreneurial intuition and imagination and must precede the 'economic' decision to go ahead with the examination of opportunities for expansion" (1959: 34). As the main actor of the dynamic entrepreneurial process, the "resource of management" molds the quality and versatility of the services currently available from resources as well as their potential in yielding enhanced and novel contributions to entrepreneurial activities (Mahoney, 1995). Much less understood and appreciated in the current entrepreneurship and resource-based view research, this second level of heterogeneity may be the more promising level of analysis to study the subjective process of entrepreneurial creativity and discovery in firms (Kor, Mahoney \& Michael, 2007). Understanding this process requires close attention to the dynamic resource-management interactions during which entrepreneurial capacity of both firm's resources and the resource of management co-evolve (Mahoney, 1995).

\section{The Subjective and Firm-Specific Nature of Entrepreneurial Discovery}

Firm development and entrepreneurial growth is an evolutionary and cumulative process of experimentation and learning about resources (Hayek, 1968; Spender, 1996) where resources and capabilities may serve as cognitive drivers for strategy (Itami \& Roehl, 1987). As Mahoney puts it: “[m]anaging involves a[n entrepreneurial] discovery procedure in which heterogeneous models of managers using heterogeneous firm-specific resources are involved in an ongoing 
competition" (1995: 97). Penrose (1959) also emphasizes that the heterogeneity in the activities produced by material and human resources is inextricably intertwined with the heterogeneity of managerial mental models (Fiol, 1991). While employees at all levels in the organization produce entrepreneurial services, it is the managerial foresight and focus on continuous "resource and organizational learning" (Grant, 1996; Spender, 1996) that produces a synergistic effect on superior development of these entrepreneurial services. In terms of the heterogeneity of entrepreneurial visions in firms, Penrose states that in the process of growth: "the imaginative effort, the sense of timing, and the instinctive recognition of what will catch on or how to make it catch on become of overwhelming importance. These services are not likely to be equally available to all firms. For those who have them, however, a wider range of investment opportunities lies open than to firms with a less versatile type of enterprise" (1959: 37). ${ }^{7}$

Indeed, capital or resource heterogeneity can now be understood as directly linked to the entrepreneurial function. Lachmann states that: "[T] he entrepreneur's function ... is to specify and make decisions on the concrete form the capital resources shall have. He specifies and modifies the layout of his plant ... As long as we disregard the heterogeneity of capital, the true function of the entrepreneur must also remain hidden" (1956: 16). The entrepreneurial function involves imagination and discovery of new services that the resources may potentially yield.

It is also important to note that managers' entrepreneurial perceptions and imagination are not formed in a vacuum, independent of the firm's resources. Subjective managerial perceptions and decisions are shaped by the attributes of resources (e.g., availability, versatility, and specificity of resources) and managers' experiential knowledge of these attributes. Penrose maintains that: "the experience of management will affect the productive services that all of its

\footnotetext{
${ }^{7}$ Spender (2006) maintains that: "Penrose's [1959] model of managerial learning [is] an accessible instance of the epistemological approach proposed by Austrian economists such as Hayek, Kirzner, and Schumpeter." In the current paper, we concur that Penrose's (1959) emphasis on "subjective opportunity set" incorporates the view of entrepreneurship as alertness. In addition, we maintain that Penrose' (1959) model of learning incorporates Knight's (1921) theory of entrepreneurship as judgment. Indeed, alertness and judgment may be usefully thought of as complementary entrepreneurial capabilities. We add that these entrepreneurs would still need "team time" to be able to combine their skills synergistically.
} 
other resources are capable of rendering. As management tries to make the best use of resources available, a truly 'dynamic' interacting process occurs which encourages continuous growth but limits the rate of growth" (1959: 5). Managers must take into account dynamic adjustment costs in solving a "jig-saw puzzle" of effective development and deployment of resources.

Penrose (1959) gives central attention to firm-level growth not just because it is the reward for entrepreneurial productivity, but also because firm-level growth is viewed as an entrepreneurial process. In this process, a scarcity of firm-specific managerial talent (i.e., managers with experiential and tacit knowledge of the firm's resources) acts as the primary limit on the rate of firm growth (also known as the Penrose effect, see, e.g., Tan \& Mahoney, 2005). Penrose states that: “... since the services from 'inherited' managerial resources control the amount of new managerial resources that can be absorbed, they create a fundamental and inescapable limit to the amount of expansion a firm can undertake at any time" (1959: 48). The firm-specificity of the knowledge possessed by the manager makes it difficult to transfer human skills, expertise, and experience developed in one firm to another firm (Bailey \& Helfat, 2003; Rubin, 1973). Even though certain managerial skills are generic and transferable, integrating a new manager's attributes with the characteristics of the firm's existing resources incurs dynamic adjustment costs (Penrose, 1959; Prescott \& Visscher, 1980; Slater, 1980).

Until the new managers develop sufficient firm-specific knowledge, these managers may not intuitively understand the casually ambiguous connections between the firm's strategic resources, its (process) activities, and its economic returns, due in part to the idiosyncratic complexity within the firm and its interdependencies with the market (Mosakowski, 1997). Thus, as a key theoretical insight, we propose that entrepreneurial discovery processes are inherently both subjective and firm specific. This proposition underscores that when managers' subjective perceptions of the firm's productive possibility set are formed without the tacit and intimate knowledge of resources, their subjective imagination and expectations about the potential 
services that the resources can render may be misinformed and unfit. Further, this proposition suggests that the value of a particular resource (owned by the firm or its competitors) to an entrepreneur can be drastically different from its market value because this entrepreneur can perceive a unique strategic opportunity in the use of this resource, given the entrepreneur's idiosyncratic information about how it may be productively deployed with the rest of the firm's assets (Denrell, Fang, \& Winter, 2003). Given these important implications, we consider in the following section the subjective and firm-specific nature of entrepreneurial judgment for developing a subjectivist theory of team entrepreneurship. Table 1 summarizes the insights obtained from the synthesis developed to this point in the current paper vis-à-vis the main sources of the synthesis.

Insert Table 1 about here

\section{SUBJECTIVISM AND TEAM ENTREPRENEURSHIP}

The vital connections between the heterogeneity of services from resources and the heterogeneity of managerial mental models are often under-appreciated in both entrepreneurship and strategy research (Mosakowski, 1998b). Both research literatures have much to gain from closer attention to how resources "become" heterogeneous as managers create or discover the services that may be rendered from resources, and how this process involves managers' functioning as an entrepreneurial team to develop a unique vision of the firm's productive opportunity set. Toward this end, we suggest how the consistent application of subjectivism can lead to new insights in theory and practice in entrepreneurship and strategic management.

A fundamental insight that we incorporate into our subjectivist theory of team entrepreneurship is that resource attributes are not given, but are created through entrepreneurial action. Sustainable competitive advantage is not generated simply through resources themselves, 
but through subjectively perceived services of those resources. There are deep connections between the "management of resources" and the "resource of management" and in particular in the effective management of the human skill bases of the firm. Unlike physical resources, human resources possess the abilities "to learn and improve their services, to transfer their knowledge from one domain to many others, and to combine resources in increasingly productive ways" (Farjoun, 1998: 613). As a result of human-resource learning, services attained both from the human resources and the material resources increase (Penrose, 1959). In our proposed subjectivist theory of team entrepreneurship, human resources and resource learning are key contributors to a firm's evolving bundle of productive resource services.

The capacities of human resources in organizational settings are neither fixed nor can be scientifically engineered, although the entrepreneurial, organizational and competitive conditions in which the human resources are embedded substantially influence these capacities. A firm's managers can play a crucial role in shaping this environment as they impact the systems, processes, and routines for developing, organizing, allocating, and motivating human resources (Lado \& Wilson, 1994). Indeed, entrepreneurial perceptions, preferences, and foresight directly influence the product and processes of capability development and renewal through human skill bases of the firm (Coff, 1997). Because these specific human resource systems can be a catalyst for the continuous development and renewal of firm-level capabilities, these human-resource systems provide the foundation of dynamic capabilities (Zahra, Sapienza \& Davidsson, 2006).

Thus, incorporating subjectivism more consistently in entrepreneurship and strategy research requires dealing constructively with both individual creativity and the partly unpredictable nature of knowledge-creation processes (O’Driscoll \& Rizzo, 1985). The manager's "image" (Boulding, 1956) gives rise to a subjective productive opportunity of the firm (Penrose, 1959: 42) and is a driver of firm heterogeneity via differential absorptive capacity (Cohen \& Levinthal, 1990; Zahra \& George, 2002). Frequently, managers' past decisions, 
decision rules, and tacit understandings derived from experience are the basic genetics which firms possess (Mahoney, 1995). In addition to highlighting the subjective nature of individuals' creativity, knowledge, and expectations, the current paper emphasizes that entrepreneurship often occurs as a creative team act, in which heterogeneous managerial mental models interact and produce a collective entrepreneurial judgment. We focus on outlining a subjectivist approach to team entrepreneurship in the following section.

\section{A Subjectivist Approach to Team Entrepreneurship}

Most of the entrepreneurship literature takes the individual entrepreneur as the unit of analysis. Only in what might be called the "market structure" approaches to entrepreneurship (e.g., Audretsch \& Keilbach, 2007) - in which the unit of analysis is the firm, industry, or cluster, and the measure of entrepreneurship is new firm formation, growth, or innovation - are groups or teams modeled as "entrepreneurial." While the current paper's subjectivist view of entrepreneurship highlights individual-level differences in preferences, knowledge, and expectations as sources of creativity, we emphasize that entrepreneurial behaviour is embedded in a social context, such as the composition of the entrepreneurial management team (Kor, 2003).

In a subjectivist approach to team entrepreneurship a firm's productive possibility set is often envisioned and enacted by an entrepreneurial management team. This team involves heterogeneous managerial mindsets that are engaged in subjective processes of discovery, creativity, and learning. Subjectivism also serves as a key property of teams in the sense that, given the bundle of heterogeneous mental models, each management team will be unique in the productive opportunity set that is collectively envisioned. Our approach underscores that entrepreneurial discovery and team entrepreneurship are intimately connected (Harper, 2006). Two essential elements that support this connection are: (1) the heterogeneity of entrepreneurial 
services in the entrepreneurial team; and (2) the shared experiences within the team possessing "knowledge of the particular circumstances of time and place" (Hayek, 1945: 521).

First, we emphasize that heterogeneity in the range and versatility of entrepreneurial services produced by material and human resources is inextricably intertwined with the heterogeneity of managerial mental models (Barr, Stimpert, \& Huff, 1992; Fiol, 1991). While all three forms of heterogeneity discussed in the current paper (i.e., heterogeneity of resources, productive services from resources, and managerial mental models) jointly and interactively form the basis of competition and (sustainable) competitive advantages, the heterogeneity of managerial mental models matters distinctly in the scope and depth of influence it can have on the unique entrepreneurial capacities of the firm.

Heterogeneity of mental models in entrepreneurial teams results from including managers with different entrepreneurial skills in the team, which can boost the likelihood of success for entrepreneurial action. Mosakowski (1998a) suggests that in team entrepreneurship, the team members with greater creativity and alertness may be better suited to identify and initiate the entrepreneurial activity whereas team members with more intuition and foresight may be better suited to coordinate and control the entrepreneurial activity. With diversity in experience and cognitive models, the entrepreneurial team is more likely to consider a wider range of strategic options in decision-making and to avoid groupthink and behavioral inertia (Eisenhardt \& Schoonhoven, 1990). Heterogeneity in the level of tacit knowledge about the firm and industry, for example, can enrich the team's cognitive resources and stimulate vigorous discussions about new entrepreneurial initiatives, which can be especially important in highly competitive and complex environments (Carpenter, 2002; Rajagopalan \& Datta, 1996) where versatile cognitive resources are needed to produce creative resource combinations.

It is also important to emphasize that heterogeneity among the entrepreneurial management team brings potential costs as well as benefits. High levels of heterogeneity in the 
team may exacerbate goal conflicts (Hambrick, Cho \& Chen, 1996), which can interrupt the processes of collective entrepreneurial discovery. High levels of conflict can potentially even block the emergence of a synergistic cognitive synthesis and a vital "dominant logic" within the entrepreneurial team (Prahalad \& Bettis, 1986). In order for the heterogeneity of managerial mental models to serve as an asset for entrepreneurial discovery, it is essential that there are positive dynamics in the entrepreneurial team, which requires shared experiences within the team with specificity in time and place. Various types of leadership dynamics can emerge through discourse and interactions (Barry, 1991) that can facilitate entrepreneurial discovery.

Regarding the importance of shared team-specific experiences of managers and employees, Penrose (1959: 46) maintains that an organizational team is "something more than a collection of individuals; it is a collection of individuals who have had experience in working together, for only in this way can be 'teamwork' be developed. Existing managerial personnel provide services that cannot be provided by personnel newly hired from outside the firm, not only because they make up the administrative organization which cannot be expanded except by their own actions, but also because the experience they gain from working within the firm and with each other enables them to provide services that are uniquely valuable for the operations of the particular group with which they are associated." Just as the economic value and characteristics of bundles of resources can change dramatically with marginal changes in the makeup and deployment of the bundle, the economic value and characteristics of bundles of managerial resources are highly sensitive to the interactions among members of the managerial team and their joint interactions with the team's tangible resources.

Positive team dynamics at the management level matters to entrepreneurship as a process of collective learning and decision-making (March, 1991; Simon, 1991). Through discussions and debates on entrepreneurial initiatives and decisions, managers learn each other's strengths, weaknesses, and idiosyncratic habits (Kor, 2003; Penrose, 1959). This learning process involves 
developing an intimate understanding of the heterogeneous mental models within the team concerning their company, markets, and competitors. A cognitive synthesis emerges from this social process, non-linearly capturing different subjective perceptions of managers, and often resulting in changes in managers' heterogeneous mental models. Thus, in team entrepreneurship, a synergistic cognitive synthesis requires both diverse mental models within the management team that bring together complementary entrepreneurial skills, and shared team-specific experience to facilitate group experimentation, cooperation, and learning.

Bringing together these essential elements of team entrepreneurship promotes superior entrepreneurial judgment for the firm while helping to create a team that focuses on entrepreneurial efforts rather than on group process issues. As the experiential knowledge of the skills and habits of the team members prepares them for taking risky endeavours and saves time in coordination (Kor \& Mahoney, 2000), the team can fully deploy its bundle of entrepreneurial skills to pursue the set of productive opportunities discovered by its members.

In the subjectivist approach to entrepreneurship developed here, the product of team entrepreneurship is a cognitive and creative team output that is unique. Given the cognitive and creative differences among the management teams, managerial teams differ with respect to the services that these teams extract from resources. The entrepreneurial team output reflects elements of subjectivism. The cognitive and creative team output constitutes a complex synthesis of the heterogeneous expectations, knowledge, and perceptions of the individual team members. Yet for this synthesis to emerge, it is necessary that team members have sufficient time to collaborate and experiment together.

Now the building blocks of the foundation of team entrepreneurship have been identified, we next discuss the conditions that reinforce and maintain this foundation. These building blocks of team entrepreneurship reveal key factors that enable and/or constrain successful collaboration. 


\section{Sustaining Team-Based Entrepreneurship}

If subjectivism (i.e., heterogeneity of perceptions, knowledge, and expectations) is at the heart of entrepreneurship both at individual and team levels, then firms must assure that their organizational environment is closely matched to their heterogeneity of mental models (e.g., diversity of ideas and entrepreneurial skills) at all levels, especially at upper-level management. Frequently, firms lack such diversity at the upper ranks because existing managers often prefer hiring or promoting individuals that are demographically similar to themselves as such individuals may have similar mindsets (Finkenstein \& Hambrick, 1996; Westphal \& Zajac, 1995). However, an organization composed of managers with very similar perceptions of the potential services from firm's resources and the competitive environment is likely to have a truncated set of productive opportunities. In team entrepreneurship, the team can be as effective as the creative inputs provided by its members, which can expand and be enriched when members learn from each others' diverse ideas, perceptions, and expectations (i.e., developing a synergistic cognitive synthesis). Also, with the inclusion of complementary skills in the team, the cooperative entrepreneurial team can typically overcome the limitations of its individual members (Barnard, 1938).

The importance of team entrepreneurship highlights the practical relevance of the organization's creation and maintenance of a firm's human capital bases (Hitt, Ireland, Shimizu \& Kochar, 2001). Recruitment and retention strategies that enable heterogeneity of mental modes at all levels in the organization facilitate an entrepreneurial environment where creativity can flourish. It is critical to develop an informal organization or culture that encourages continuous resource learning through interactions in teams. In the absence of leadership values and organizational efforts to promote human capital development, neither individual resources nor the firm can hope to reach their entrepreneurial capacities (Barry, 1991; Ireland, Hitt, \& Sirmon, 2003; Kor \& Leblebici, 2005; Lado \& Wilson, 1994). Indeed, under conditions that inhibit 
creative thinking, entrepreneurial experimentation, and risk taking, human resources are likely to function substantially below their full entrepreneurial capacity. Contemporary entrepreneurship theories need to identify conditions that encourage entrepreneurial creativity and to address how to avoid the stifling of creativity that plagues many firms. This proposed objective suggests that entrepreneurship and strategic management (especially the resource-based view) will need to take a turn toward considering the processes of individual and organizational learning (Mahoney, 1995; March, 1991; Mosakowski, 1997).

In the current paper, we do not provide a detailed blueprint for an administrative framework and culture that promotes entrepreneurial productivity. Instead, we identify and discuss some of the crucial elements of an organizational environment that encourages team entrepreneurship and resource learning. First, as a fundamental requirement, entrepreneurial creativity and discovery requires that individuals have freedom and opportunities in order to imagine different services of resources, to deploy individual entrepreneurial capital, to renew the firm's unique productive opportunity set, and to "mobilize invisible assets" (Itami \& Roehl, 1987). Individuals are not only allowed to think creatively, but are also encouraged to voice their creative ideas and visions about new product ideas and novel ways to utilize resources.

Further, an entrepreneurially stimulating environment provides individuals with resource flexibility and slack for calculative experimentation (Barry, 1991; Dobrev \& Barnett, 2005; Mosakowski, 1997), which helps mobilize the cognitive assets of the firm that are in the form of heterogeneous mental models. Resource learning and organizational learning involve taking risks, making mistakes, and experimenting with novel solutions and ideas. Pervasive fear of failure and punishment instilled in employees does not belong to entrepreneurial environments, as it can severely constrict risk- taking and resource learning (McGrath \& McMillan, 2000). Besides seeking creative thinking, effective entrepreneurship requires investments in ideas and rewarding entrepreneurial thinking and experimentation both at the individual level and at the 
team level to achieve what classical organization theory calls an "inducement-contributions" balance (Barnard, 1938, Simon, 1945). An effective allocation of inducements to encourage entrepreneurial efforts requires recognition of the heterogeneity of individual needs, as some individuals are more interested in material benefits while others are more motivated by social benefits and entrepreneurial engagement. An effective "entrepreneurial" organizational structure is one that encourages employees to exercise creativity, experiment, and learn in ways that increase an organization's economic value while discouraging unproductive rent-seeking behavior (Foss \& Foss, 2001; Foss, Foss \& Klein, 2007). The allocation of property rights and the characteristics of the employment relationship are thus important in facilitating entrepreneurial judgment that is in the service of these organizations, and ultimately society.

Furthermore, the element of time as a scarce resource (Mahoney, 2005; Mosakowski, 1993) deserves special attention in entrepreneurship research because developing a productive opportunity set for the firm requires personal (tacit) knowledge of the firm's material and human resources, which can only be developed over time as entrepreneurs interact and experiment with the firm's bundle of resources. In forming a productive possibility set for the firm, managers benefit from taking an experimental approach where these managers start with initial expectations, and adjust their expectations continuously as they experiment, learn, and improve their knowledge of the firm's resources and markets (in a Bayesian fashion) after going through a series of these experiments in a specific firm can managers make well-informed strategic decisions under conditions of causal ambiguity (Mosakowski, 1997). Firm-specific knowledge is an important part of a managers' entrepreneurial capital since managers possessing firm-specific experiences may envision an intuitive and better informed subjective productive opportunity set for the firm (Kor \& Mahoney, 2000). Moreover, bringing together heterogeneous managerial mental cognitive inputs for team entrepreneurship also underscores the importance of time, 
because only with experience that involves specificity in time and place, can these entrepreneurs "think and function together" to produce synergistic cognitive outcomes.

Ketchen notes that: "it would be difficult to choose a topic of greater practical significance than entrepreneurship" (2003: 281). We concur, and we provide implications of practical relevance to entrepreneurs. One important practical implication of this subjectivist theory of team entrepreneurship is that despite the availability of abundant opportunities in the environment, rapid expansion of a firm's entrepreneurial team and the level of its creative output cannot be successfully achieved in a short time span because absorption of new team members, new technology, and new business knowledge increases the demand for entrepreneurial time and attention (Penrose, 1959; Simon, 1991). This line of reasoning suggests that entrepreneurial teams should maintain a firm-specific knowledge base through members who have experiential knowledge of the firm's unique set of resources and capabilities to increase the likelihood that well-informed entrepreneurial judgments are made.

Likewise, for the new team members, the experiential knowledge and superior heuristics of the firm can only be gained over time (Amit \& Schoemaker, 1990; Kor \& Leblebici, 2005). Without experiential knowledge of the firm's resources, routines, language, and predispositions, and the tacit knowledge of team members' cognitive frameworks and idiosyncratic habits that helps to build a fabric of trust (see e.g., Arrow, 1974), entrepreneurial teams cannot envision valuable resource combinations that help create unique strategic opportunities. This line of reasoning suggests that newly formed entrepreneurial teams should not be disrupted extensively by frequent changes in team composition. Based on these practical implications, we emphasize that sustained entrepreneurial productivity requires "internally knowledgeable" team entrepreneurship and an organizational environment (including effective governance) that encourages cognitive heterogeneity and resource learning. Figure 1 illustrates our theoretical model on team entrepreneurship. 
Insert Figure 1 about here

Besides the practical implications of a subjectivist approach to entrepreneurship, the approach described in this paper can inform research agendas in several areas of management inquiry that we discuss below. We turn now to conclusions and our suggested research agenda.

\section{CONCLUSIONS AND DIRECTIONS FOR FUTURE RESEARCH}

What difference would it make if these fundamental insights about the subjective and social processes of learning and entrepreneurial discovery went unnoticed by the mainstream entrepreneurship and strategy researchers? For starters, we would miss an opportunity to strengthen our theories by more accurately describing and explaining the nature and dynamics of entrepreneurial discovery. In their current state, our existing theories - built on economic concepts of entrepreneurship that treat the entrepreneurial act as a black box - do not acknowledge that entrepreneur can occur as a creative act by entrepreneurial teams, where heterogeneous managerial mental models interact in a process that produces a collective output, which is cognitively and creatively superior to individual entrepreneurship.

In the current paper, we also emphasize that contemporary entrepreneurship theories should identify key factors that enable and/or constrain individual creativity and team entrepreneurship. By uncovering the micro- and macro-conditions that stimulate entrepreneurial creation, discovery, and productivity, we can offer decision-makers superior heuristics that enhance the likelihood of improved performance outcomes (Mosakowski, 1998b). Currently, there is limited systematic research in management on the processes by which new resource services are discovered or created, and on how organizational structure, incentives, and governance mechanisms affect the creation and use of valued attributes (Foss, Foss \& Klein, 2007). Thus, future research that further explores the conditions that enable and/or constrain 
innovative activity at various levels of entrepreneurship such as the team, the firm, and the economy appear promising.

A subjectivist approach to entrepreneurship significantly benefits from the contributions of Penrose (1959) and from the Austrian School of economics. Our synthesis of key insights from these perspectives enables the development of a new and integrative subjectivist theory of team entrepreneurship. This subjectivist theory emphasizes the nature and processes for cocreation and collective entrepreneurial discovery. A key proposition of the current paper is that resources are not given, but must be discovered, or created, over time, as managers interact with the firm's tangible and intangible assets, other members of the managerial team, and their competitive landscapes. Because resource attributes are subjective, and, in the current theory, are ultimately determined by the managers' subjective values, knowledge, and beliefs, firms are inherently heterogeneous, even when possessing similar "objective" characteristics. Furthermore, the firm is best understood not only as a repository of tacit, subjectively understood knowledge, but also a mechanism by which heterogeneous managerial mental models are brought together and given the necessary resources and internal environment to create a collective synthesis. This synthesis is the creative and cognitive product of team entrepreneurship, which incorporates collective entrepreneurial judgment about the firm's productive opportunity set.

The suggested research approach provided here implies a positive research agenda to better understand firm-level behavior and their performance consequences. We need to study how organizational and environmental factors shape managers' values, knowledge, and expectations, both individually and in team settings. As Penrose notes: "If we can discover what determines entrepreneurial ideas about what the firm can and cannot do, that is, what determines the nature and the extent of the 'subjective' productive opportunity of the firm, we can at least know where to look if we want to explain or to predict the actions of a particular firm" (1959: 42). The relationship between this subjective productive opportunity set and firm-level strategy 
is subtle, complex, and at least partly endogenous. While the current paper emphasizes that the attributes of the entrepreneurial team may be a binding constraint on the rate at which the firm grows and diversifies, new research may also uncover ways in which the (planned and organic) growth processes of firms enable developing firm's capabilities, which may facilitate processes of entrepreneurial learning that spur the rate of growth.

Moreover, our subjectivist approach to entrepreneurship emphasizes the importance of heterogeneity of managerial mental models for team entrepreneurship. Thus, future research can explore how firms can assemble diverse but complementary entrepreneurial skills in teams to promote entrepreneurial productivity. Equally useful would be to identify a bundle of analytical and social skills for effective entrepreneuring (Barry, 1991) and to examine empirically the value (e.g., the impact on innovation and economic returns) of alternative configurations of these skills for team entrepreneurship. Clearly, such empirical research must give close attention to the unique aspects of the firm such as the specific business model and its competitive, technology, and regulatory environment, because such contingencies may call for a unique bundle or configuration of entrepreneurial team skills.

We also suggest that the firm's organizational structure, culture, and property rights governance mechanisms either facilitate or inhibit processes of experimentation, learning, and creativity within the entrepreneurial team. Further research that delineates in greater detail the rich connections among organizational structure, culture, property rights, human resource management, incentives, and entrepreneurial creativity is vitally needed. Equally important, the competitive landscape and regulatory also affects managers' abilities to formulate production plans, create or discover resource attributes or services, and adjust their beliefs according to new information. Rapid technological change, regulatory shocks, and other industry-specific disruptions are associated with increased experimentation but also greater "noise," leading to higher rates of ex-post reversal among entrepreneurial decisions (Klein \& Klein, 2001). The 
integration of the entrepreneurship and strategic management literatures may prove quite useful for public policy debates (Barney, 2005; Mahoney \& McGahan, 2007).

Barney, Wright and Ketchen (2001) suggest that the next generation of research on resource-based theory should include connections with entrepreneurship, human-resource management and international business. While the focus of the current paper has been on connecting a subjectivist theory of resource learning to entrepreneurship, strategic management, and human resource-management, our approach also has implications for international business research. Entrepreneurship liberalizes the economy, promotes foreign innovation, infuses new technology, and increases standards of living (Zahra, Ireland, Gutierrez \& Hitt, 2000). The growing relevance of entrepreneurship worldwide for the economic development of poorer nations and the continuing capabilities of wealthier nations to create economic wealth is apparent. Extending the current paper's focus on firm-level entrepreneurship, future international business research may usefully consider the rich connections among a nation's constitutional frameworks, societal norms and culture, property rights, incentives, and entrepreneurial creativity. We anticipate that research in cognitive science will provide fruitful avenues for understanding how belief systems and ideologies change over time (North, 2005).

In conclusion, we hope that both the contents of the current paper and the research agenda we provide in the concluding sectionresonates across multiple Divisions within the Academy of Management such as Business Policy \& Strategy, Entrepreneurship, Human Resource Management, International Business, and Organization Theory, to name but a few. The substantial future research opportunities afforded by a subjectivist theory of team entrepreneurship to management scholars across a wide spectrum of research interests suggests much promise. 


\section{REFERENCES}

Alchian, A. A., \& Demsetz, H. 1972. Production, information costs, and economic organization. American Economic Review, 62: 777-794.

Aldrich, H. E., \& Wiedenmayer, G. 1993. From traits to rates: An ecological perspective on organizational foundings," in J. Katz and R. Brockhaus, eds., Advances in Entrepreneurship, Firm Emergence, and Growth. Greenwich, Conn.: JAI Press, pp. 145-95.

Alvarez, S. A., \& Barney, J. B. 2004. Organizing rent generation and appropriation: Towards a theory of the entrepreneurial firm. Journal of Business Venturing, 19: 621-635.

Alvarez, S. A., \& Barney, J. B. 2005. Discovery and creation: Alternative theories of entrepreneurial action," unpublished manuscript.

Alvarez, S. A., \& Busenitz, L. W. 2001. The entrepreneurship of resource-based theory. Journal of Management, 27: 755-775.

Amit, R. H., \& Schoemaker, P. J. H. 1993. Strategic assets and organizational rent. Strategic Management Journal, 14 (1): 33-46.

Ardichvili, A., Cardozo, R., \& Ray, S. 2003. A theory of entrepreneurial opportunity, identification and alertness. Journal of Business Venturing, 19 (5): 637-658.

Arrow, K. J. 1974. The Limits of Organization. New York, NY: W.W. Norton \& Company.

Audretsch, D. B., \& Keilbach, M. 2007. The theory of knowledge-spillover entrepreneurship. Journal of Management Studies, forthcoming.

Bailey, E. E., \& Helfat, C. E. 2003. External management succession, human capital, and firm performance: An integrative analysis. Managerial and Decision Economics, 24: 347-369.

Barnard, C. I. 1938. The Functions of the Executive. Cambridge, MA: Harvard University Press.

Barney, J. B. 1991. Firm resources and sustained competitive advantage. Journal of Management. 17 (1): 99-120.

Barney, J. B. 2005. Should strategic management research engage public policy issues? Academy of Management Journal, 48 (6): 945-948.

Barney, J., Wright, M. \& Ketchen, D. J. 2001. The resource-based view of the firm: Ten years after 1991. Journal of Management, 27 (6): 625-641.

Barr, P. S., Stimpert, J. L., \& Huff, A. S. 1992. Cognitive change, strategic change, and organizational renewal. Strategic Management Journal, 13 (Summer): 15-36.

Barry, D. 1991. Managing the bossless team: Lessons in distributed leadership. Organizational Dynamics, 21 (1): 31-47. 
Baumol, W. J. 1993. Entrepreneurship, Management and the Structure of Payoffs. Cambridge, MA: MIT Press.

Böhm-Bawerk, E. V. 1889. The Positive Theory of Capital. 1923 reprint of 1891 Smart translation, New York, NY: Stechert

Boulding, K. E. 1956. The Image. Ann Arbor, MI: University of Michigan Press.

Buchanan, J. M. 1969. Cost and Choice: An Inquiry in Economic Theory. Chicago: Markham Publishing Company.

Busenitz, L. W. 1996. Research on entrepreneurial alertness. Journal of Small Business Management, 34 (4): 35-44.

Cantillon, R. 1755. Essai Sur La Nature de Commerce en General. H. Higgs, ed., London: Macmillan, 1931.

Carpenter, M.A. 2002. The implications of strategy and social context for the relationship between top management team heterogeneity and firm performance. Strategic Management Journal, 23: 275-284.

Casson, M. C. 1982. The Entrepreneur: An Economic Theory. Oxford: Martin Robertson, 2nd. edition, Edward Elgar, 1999.

Coff, R. W. 1997. Human assets and managerial dilemmas: Coping with hazards on the road to resource-based theory. Academy of Management Review, 22 (2): 374-402.

Cohen, W. M., \& Levinthal D. A. 1990. Absorptive capacity: A new perspective on learning and innovation. Administrative Science Quarterly, 35 (1): 128-152.

Conner, K. R., \& Prahalad, C. K. 1996. A resource-based theory of the firm: Knowledge versus opportunism. Organization Science, 7 (5): 477-501.

Denrell, J., Fang, C., \& Winter, S. G. 2003. The economics of strategic opportunity. Strategic Management Journal, 24: 977-990.

Dierickx, I., \& Cool K. 1989. Asset accumulation and sustainability of competitive advantage. Management Science, 35: 1504-1511.

Dobrev, S. D., \& Barnett, W. P. 2005. Organizational roles and transition to entrepreneurship. Academy of Management Journal, 48 (3): 433-463.

Eisenhardt, K.M., \& Schoonhoven, C. B. 1990. Organizational growth: Linking founding team, strategy, and growth among U.S. semi-conductor ventures, 1978-1988. Administrative Science Quarterly, 35: 504-29.

Farjoun, M. 1998. The independent and joint effects of the skill and physical bases of relatedness in diversification. Strategic Management Journal, 19: 611-630. 
Finkelstein, S., \& Hambrick D. C. 1996. Strategic Leadership: Top Executives and Their Effects on Organizations. St. Paul, MN: West Publishing Company.

Fiol C. M. 1991. Managing culture as a competitive resource: An identity-based view of sustainable competitive advantage. Journal of Management, 17(1): 191-211.

Foss, K., \& Foss, N. J. 2001. Assets, attributes and ownership. International Journal of the Economics of Business, 8(1): 19-37.

Foss, K., Foss, N. J., \& Klein, P. G. 2007. Original and derived judgment: An entrepreneurial theory of economic organization. Organization Studies, forthcoming.

Foss, K., N. J. Foss, Klein, P. G., \& Klein, S. K. 2007. The entrepreneurial organization of heterogeneous capital. Journal of Management Studies, forthcoming.

Foss, N. 1998. Austrian and post-Marshallian economics: The bridging work of George Richardson. In N. Foss and B. Loasby (eds.). Economic Organization, Capabilities, and Coordination: Essays in Honor of G. B. Richardson. London: Routledge.

Foss, N. 2002. Edith Penrose, economics, and strategic management. In Pitelis, C., ed. (2002). The Growth of the Firm: The Legacy of Edith Penrose. New York, NY: Oxford University Press.

Foss, N. J., \& Klein, P. G. 2005. Entrepreneurship and the economic theory of the firm: Any gains from trade? In R. Agarwal, S. A. Alvarez, and O. Sorenson (eds.), Handbook of Entrepreneurship: Disciplinary Perspectives, Norwell, MA: Kluwer, pp. 55-80.

Ghemawat, P. 1991. Commitment: The Dynamic of Strategy. New York, NY: Free Press.

Grant, R. M. 1996. Toward a knowledge-based theory of the firm. Strategic Management Journal, 17 (Winter): 109-122.

Hambrick, D. C., Cho, S. T., \& Chen, M-J. 1996. The influence of top management team heterogeneity on firms' competitive moves. Administrative Science Quarterly, 41 659-684.

Harper, D. A. 2006. Towards a theory of entrepreneurial teams. New York, NY: New York University, working paper.

Hayek, F. A. 1941. The Pure Theory of Capital. Chicago, IL: University of Chicago Press.

Hayek, F. A. 1945. The use of knowledge in society. American Economic Review, 35: 519-530.

Hayek, F. A. 1948. Individualism and Economic Order. Chicago, IL: University of Chicago Press.

Hayek, F.A. 1955. The Counter-revolution of Science: Studies in the Abuse of Reason. Indianapolis, IN: Liberty Press.

Hayek, F. A. 1968. Competition as a discovery procedure. Translated by M. S. Snow. Quarterly Journal of Austrian Economics 5 (3): 9-23. 
Helfat, C. E. 1997. Know-how and asset complementarity and dynamic capability accumulation: the case of R\&D. Strategic Management Journal, 18: 339-360.

Hill, C. W. L., \& Deeds, D. L. 1996. The importance of industry structure for the determination of firm profitability: A Neo-Austrian perspective. Journal of Management Studies. 33: 429-451.

Hitt, M.A., Bierman, L., Shimizu, K., \& Kochhar R. 2001. Direct and moderating effects of human capital on strategy and performance in professional service firms: A resource-based perspective. Academy of Management Journal, 44(1): 13- 28.

Hitt, M. A., R. D. Ireland, S. M. Camp, \& Sexton, D. L. 2001. Strategic entrepreneurship: Entrepreneurial strategies for wealth creation. Strategic Management Journal, 22 (6): 479-492.

Ireland, R.D., Hitt M.A., \& Sirmon D.G. 2003. A model of strategic entrepreneurship: The construct and its dimensions. Journal of Management, 29(6): 963-989.

Itami, H., \& Roehl, T. 1987. Mobilizing Invisible Assets. Cambridge, MA: Harvard University Press.

Jacobson, R. 1992. The 'Austrian' school of strategy. Academy of Management Review, 17 (4): 782-807.

Ketchen, D. J. 2003. Entrepreneurship: Past accomplishment and future challenges. Journal of Management, 29 (3): 281-283.

Kim, J., \& Mahoney, J. T. 2006. How property rights economics furthers the resource-based view: Resources, transaction costs and entrepreneurial discovery. International Journal of Strategic Change Management, forthcoming.

Kirzner, I. M. 1966. An Essay on Capital. New York, NY: Augustus M. Kelley.

Kirzner, I. M. 1973. Competition and Entrepreneurship. Chicago, IL: University of Chicago Press.

Kirzner, I. M. 1979. Perception, Opportunity and Profit: Studies in the Theory of Entrepreneurship, Chicago and London: University of Chicago Press, 1983 (reprint edition).

Kirzner, I. M. 1997. Entrepreneurial discovery and the competitive market process: An Austrian approach. Journal of Economic Literature, 35 (March): 60-85.

Klein, P. G., \& Klein S. K. 2001. Do entrepreneurs make predictable mistakes? Evidence from corporate divestitures. Quarterly Journal of Austrian Economics 4 (2): 3-25.

Knight, F. H. 1921. Risk, Uncertainty, and Profit. New York, NY: August M. Kelley.

Kogut, B., \& Zander U. 1992. Knowledge of the firm, combinative capabilities, and the replication of technology. Organization Science, 3 (3): 383-397.

Kor, Y. Y. 2003. Experience-based top management team competence and sustained growth. Organization Science, 14 (6): 707-719. 
Kor, Y.Y., \& Leblebici. H. 2005. How do interdependencies among human-capital deployment, development, and diversification strategies affect firms' financial performance? Strategic Management Journal, 26(10): 967-985.

Kor, Y. Y., \& Mahoney, J. T. 2000. Penrose's resource-based approach: The process and product of research creativity. Journal of Management Studies, 37 (1): 109-139.

Kor, Y. Y., \& Mahoney, J. T. 2004. Edith Penrose's (1959) contributions to the resource-based view of the firm. Journal of Management Studies, 41 (1): 183-191.

Kor, Y.Y., Mahoney, J.T., \& Michael, S. C. 2007. Resources, capabilities and entrepreneurial perceptions. Journal of Management Studies, forthcoming.

Lachmann, L. M. 1956. Capital and Its Structure. Kansas City, MO: Sheed Andrews and McMeel, 1978.

Lachmann L. M. 1976. From Mises to Shackle: An essay on Austrian economics and the kaleidic society." Journal of Economic Literature 14 (1): 54-62.

Lachmann, L. M. 1977. Capital, Expectations, and the Market Process. Kansas City, MO: Sheed Andrews \& McNeel.

Lachmann, L. M. 1986. The Meaning of the Market Process. Oxford: Basil Blackwell.

Lado, A. A., \& Wilson, M. C. 1994. Human resource systems and sustained competitive advantage: A competence-based perspective. Academy of Management Review, 19: 699-727.

Langlois, R. N. 2007. The entrepreneurial theory of the firm and the theory of the entrepreneurial firm. Journal of Management Studies, forthcoming.

Littlechild, S. C. 1986. Three types of market processes. In R. N. Langlois, ed. Economics as a Process, Cambridge, MA: Cambridge University Press, pp. ??

Loasby, B. J. 1991. Equilibrium and Evolution: An Exploration of Connecting Principles in Economics. New York, NY: Manchester University Press.

Machlup, F. 1967. Essays in Economic Semantics. New York, NY: Norton and Company.

Machlup, F. 1978. Methodology of Economics and Other Social Sciences. New York, NY: Academic Press.

Mahoney, J. T. 2005. Economic Foundations of Strategy. Thousand Oaks, CA: Sage Publications.

Mahoney, J. T. 1995. The management of resources and the resource of management. Journal of Business Research, 33: 91-101.

Mahoney, J. T. \& McGahan, A. 2007. The field of Strategic Management within the evolving science of strategic organization. Strategic Organization, forthcoming. 
Mahoney, J. T., \& Pandian, J. R. 1992. The resource-based view within the conversation of strategic management, 13: 363-380.

March J.G. 1991. Exploration and exploitation in organizational learning. Organization Science, 2(1): 71-87.

McGrath, R. G. 2001. Exploratory learning, innovative capacity, and managerial oversight. Academy of Management Journal, 44: 118-131.

McGrath, R.G., \& MacMillan, I.C. 2000. The Entrepreneurial Mindset. Boston: Harvard Business School Press.

Menger, C. 1871. Principles of Economics. New York: New York University Press, 1985.

Mises, L. V. 1949. Human Action: A Treatise on Economics. New Haven, CT: Yale University Press.

Mosakowski, E. 1993. A resource-base perspective on the dynamic strategy-performance relationship: An empirical examination of the focus and differentiation strategies on entrepreneurial firms. Journal of Management, 19 (4): 819-839.

Mosakowski, E. 1997. Strategy making under causal ambiguity: Conceptual issues and empirical evidence. Organization Science, 8: 414-442.

Mosakowski, E. 1998a. Entrepreneurial resources, organizational choices, and competitive outcomes. Organization Science, 9: 625-643.

Mosakowski, E. 1998b. Managerial prescriptions under the resource-based view of strategy: The example of motivational techniques. Strategic Management Journal, 19: 1169-1182.

Nelson, R. R., \& Winter, S. G. 1982. An Evolutionary Theory of Economic Change. Cambridge, MA: Harvard University Press.

North, D. C. 2005. Understanding the Process of Economic Change. Princeton, N.J.: Princeton University Press.

O’Driscoll, G. P., \& Rizzo, M. 1985. The Economics of Time and Ignorance. Oxford: Basil Blackwell.

Penrose, E. T. 1959. The Theory of the Growth of the Firm. New York, NY: John Wiley.

Peteraf, M. 1993. The cornerstones of competitive advantage: A resource-based view. Strategic Management Journal, 14: 179-191.

Pitelis, C., ed. 2002. The Growth of the Firm: The Legacy of Edith Penrose. New York, NY: Oxford University Press.

Polanyi, M. 1962. Personal Knowledge: Towards a Post-Critical Philosophy. Chicago, IL: University of Chicago Press. 
Prahalad, C.K., \& Bettis, R.A. 1986. The dominant logic: A new linkage between diversity and performance. Strategic Management Journal, 7: 485-501.

Prescott, E. C., \& Visscher, M. 1980. Organizational capital. Journal of Political Economy, 88: 446-461.

Rajagopalan, N. \& Datta, D.K. 1996. CEO characteristics: Does industry matter? Academy of Management Journal, 39(1): 197-215.

Rindova, V. P., \& Kotha, S. 2001. Continuous 'morphing': Competing through dynamic capabilities, form and function. Academy of Management Journal, 44 (6): 1263-1280.

Roberts, P. W., \& Eisenhardt, K. M. 2003. Austrian insights on strategic organization: From market insights to implications for firms. Strategic Organization, 1: 345-352.

Rothbard, M. N 1962. Man, Economy, and the State. Auburn, AL: Ludwig Mises Institute [2004 edition].

Rubin, P.H. 1973. The expansion of firms. Journal of Political Economy, 81: 936-949.

Rumelt, R. P. 1987. Theory, strategy, and entrepreneurship. In D. Teece (Ed.), The Competitive Challenge, pp. 137-158. Cambridge, MA: Ballinger.

Schumpeter, J. A. 1911. The Theory of Economic Development: An Inquiry into Profits, Capital, Credit, Interest, and the Business Cycle. Translated by Redvers Opie. Cambridge, MA: Harvard University Press, 1934.

Schumpeter, J. A. 1942. Capitalism, Socialism, and Democracy. New York, NY: Harper \& Row.

Shackle, G. L. S. 1972. Epistemics and Economics. Cambridge, UK: Cambridge University Press.

Shane, S. 2003. A General Theory of Entrepreneurship: The Individual-Opportunity Nexus. Aldershott: Edward Elgar.

Shane, S., \& Venkatraman, S. 2000. The promise of entrepreneurship as a field of research. Academy of Management Review, 25 (1): 217-226.

Simon, H.A. 1945. Administrative Behavior. New York, NY: The Free Press.

Simon, H.A. 1991. Bounded rationality and organizational learning. Organization Science 2(1): 125-133.

Slater M. 1980. The managerial limitation to the growth of firms. The Economic Journal, 90: 520-528.

Sorensen, J. B., \& Sorenson, O. 2003. From conception to birth: Opportunity, perception and resource mobilization in entrepreneurship. Advances in Strategic Management, 20: 89-117. 
Spender, J. C. 1996. Making knowledge the basis of a dynamic theory of the firm. Strategic Management Journal, 17 (Winter): 45-62.

Spender, J.C. 2006. The RBV, methodological individualism, and managerial cognition: Practicing entrepreneurship. Presented at Academy of Management in Atlanta, Georgia.

Tan, D. \& Mahoney, JT. 2005. Examining the Penrose Effect in an international business context. The dynamics of Japanese firm growth in U.S. industries. Managerial and Decision Economics, 26 (2): 113-127.

Teece, D. J., Pisano, G., \& Shuen, A. 1997. Dynamic capabilities and strategic management. Strategic Management Journal, 18: 509-533.

Thornhill, S. \& Amit, R. 2001. A dynamic perspective of internal fit in corporate venturing. Journal of Business Venturing, 16: 25-50.

Venkataraman, S. 1997. The distinctive domain of entrepreneurship research.” In J. Katz, ed., Advances in Entrepreneurship, Firm Emergence, and Growth, JAI Press, pp. 119-38.

Wernerfelt, B. 1984. A resource-based view of the firm. Strategic Management Journal, 5 (2): 171-180.

Westphal, J. D., \& Zajac, E. J. 1995. Who shall govern? CEO/board power, demographic similarity, and new director selection. Administrative Science Quarterly, 40: 60-83.

Witt, U. 1998. Imagination and leadership: The neglected dimension of an evolutionary theory of the firm. Journal of Economic Behavior and Organization 35: 161-77.

Zahra, S. A., \& George, G. 2002. Absorptive capacity: A review, reconceptualization and extension. Academy of Management Review, 27 (2): 213-240.

Zahra, S., Ireland., R. D. Guiterrez, I., \& Hitt, M. A. 2000. Privatization and entrepreneurial transformation: Emerging issues and a future research agenda. Academy of Management Review, 25 (3): 509-524.

Zahra, S. A., Sapienza, H. J., \& Davidsson, P. 2006. Entrepreneurship and dynamic capabilities: A review, model and research agenda. Journal of Management Studies, 43 (4): 917-955. 
TABLE 1: Key Differences Among Focal Theories

\begin{tabular}{|c|c|c|c|c|}
\hline & $\begin{array}{l}\text { Austrian } \\
\text { Economics }\end{array}$ & $\begin{array}{l}\text { Penrose's } \\
\text { Subjectivist } \\
\text { Approach }\end{array}$ & $\begin{array}{l}\text { The Resource- } \\
\text { based View }\end{array}$ & $\begin{array}{l}\text { A Subjectivist Theory of } \\
\text { Team Entrepreneurship }\end{array}$ \\
\hline $\begin{array}{l}\text { Key } \\
\text { Contributors }\end{array}$ & $\begin{array}{l}\text { Menger (1871) } \\
\text { Hayek (1948) } \\
\text { Mises (1949) } \\
\text { Rothbard (1962) } \\
\text { Kirzner (1973) } \\
\text { Lachmann (1986) }\end{array}$ & Penrose (1959) & $\begin{array}{l}\text { Wernerfelt (1984) } \\
\text { Rumelt (1987) } \\
\text { Dierickx \& Cool } \\
\text { (1989) } \\
\text { Barney (1991) } \\
\text { Peteraf (1993) }\end{array}$ & $\begin{array}{l}\text { Bringing insights together from } \\
\text { all three perspectives, and } \\
\text { building on: } \\
\text { Mahoney (1995) } \\
\text { Kor (2003) } \\
\text { Foss, Foss, Klein (2007) } \\
\text { Kor, Mahoney, Michael (2007) }\end{array}$ \\
\hline $\begin{array}{l}\text { Explanatory } \\
\text { aims }\end{array}$ & $\begin{array}{l}\text { Explaining } \\
\text { individual and } \\
\text { social phenomena } \\
\text { in terms of } \\
\text { purposeful human } \\
\text { action, focusing on } \\
\text { subjectivism, } \\
\text { capital } \\
\text { heterogeneity, and } \\
\text { distributed } \\
\text { knowledge }\end{array}$ & $\begin{array}{l}\text { Explaining the firm's } \\
\text { growth as an } \\
\text { entrepreneurial } \\
\text { process, focusing on } \\
\text { firm's unique } \\
\text { productive } \\
\text { opportunity set } \\
\text { envisioned by the } \\
\text { management team. }\end{array}$ & $\begin{array}{l}\text { Uncovering the } \\
\text { necessary } \\
\text { conditions of } \\
\text { sustained } \\
\text { competitive } \\
\text { advantage. }\end{array}$ & $\begin{array}{l}\text { Showing how interactions } \\
\text { between heterogeneous } \\
\text { resources and heterogeneous } \\
\text { managerial mental models (i.e., } \\
\text { managers' subjective values, } \\
\text { knowledge, and expectations) } \\
\text { generate a cognitive and } \\
\text { creative team output (i.e., } \\
\text { collective entrepreneurial } \\
\text { judgment): the firm's } \\
\text { productive opportunity set. }\end{array}$ \\
\hline $\begin{array}{l}\text { Unit of } \\
\text { analysis }\end{array}$ & Human action & $\begin{array}{l}\text { Firm as a bundle } \\
\text { of resources }\end{array}$ & $\begin{array}{l}\text { Individual } \\
\text { resources }\end{array}$ & $\begin{array}{l}\text { Firm and the entrepreneurial } \\
\text { management team. }\end{array}$ \\
\hline $\begin{array}{l}\text { Mode of } \\
\text { explanation }\end{array}$ & $\begin{array}{l}\text { Process oriented; } \\
\text { traces out the } \\
\text { causal sequence } \\
\text { from human action } \\
\text { to social outcomes }\end{array}$ & $\begin{array}{l}\text { Process oriented; } \\
\text { availability of firm- } \\
\text { specific managerial } \\
\text { resources serves as } \\
\text { the bottleneck for } \\
\text { growth and } \\
\text { diversification. }\end{array}$ & $\begin{array}{l}\text { Focuses on states } \\
\text { ("equilibria") } \\
\text { where firms earn } \\
\text { sustained } \\
\text { competitive } \\
\text { advantage }\end{array}$ & $\begin{array}{l}\text { Process oriented. Focuses on } \\
\text { essential elements of team } \\
\text { entrepreneurship, including } \\
\text { positive team dynamics, } \\
\text { experiential knowledge of the } \\
\text { firm's resources, and time as a } \\
\text { scarce resource. }\end{array}$ \\
\hline $\begin{array}{l}\text { Portrayal of } \\
\text { Entrepreneurs }\end{array}$ & $\begin{array}{l}\text { Individuals who } \\
\text { exercise alertness } \\
\text { or judgment. }\end{array}$ & $\begin{array}{l}\text { Entrepreneurship is } \\
\text { exercised by a team. } \\
\text { Emphasizes alertness } \\
\text { as well as judgment. }\end{array}$ & $\begin{array}{l}\text { Entrepreneurship } \\
\text { not emphasized. }\end{array}$ & $\begin{array}{l}\text { Acknowledges individuals as } \\
\text { source of creativity, but } \\
\text { emphasizes entrepreneurship } \\
\text { as a creative team act. } \\
\text { Emphasizes judgment. }\end{array}$ \\
\hline $\begin{array}{l}\text { Concept of } \\
\text { resources }\end{array}$ & $\begin{array}{l}\text { What make some } \\
\text { goods resources } \\
\text { (i.e., capital goods) } \\
\text { is not their } \\
\text { physical } \\
\text { characteristics, but } \\
\text { their place in an } \\
\text { entrepreneur's } \\
\text { plan. }\end{array}$ & $\begin{array}{l}\text { Services, rather than } \\
\text { resources, are } \\
\text { stressed, including } \\
\text { the services of the } \\
\text { management team. }\end{array}$ & $\begin{array}{l}\text { A strategic } \\
\text { resource to one } \\
\text { firm is also a } \\
\text { strategic resource } \\
\text { to another firm. } \\
\text { Usually no } \\
\text { distinction between } \\
\text { resources and their } \\
\text { services. }\end{array}$ & $\begin{array}{l}\text { Resource heterogeneity exists } \\
\text { on three levels: } \\
\begin{aligned} & \text { 1. } \text { Resources themselves. } \\
& \text { 2. Resource Services. } \\
& \text { 3. Managerial mental } \\
& \text { models. }\end{aligned}\end{array}$ \\
\hline
\end{tabular}


FIGURE 1. Team Entrepreneurship

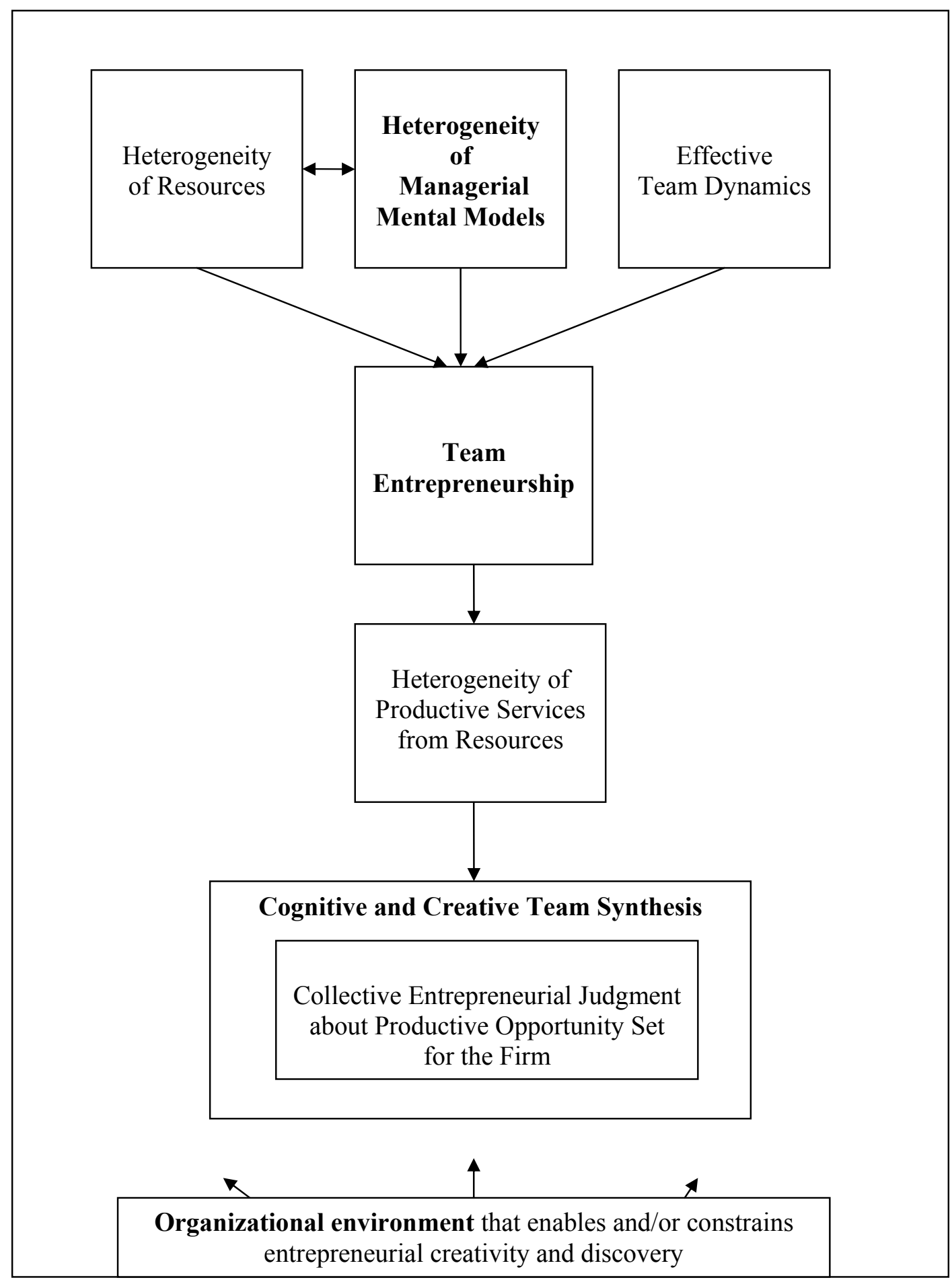




\section{SMG - Working Papers \\ www.cbs.dk/smg \\ 2003}

2003-1: Nicolai J. Foss, Kenneth Husted, Snejina Michailova, and Torben Pedersen: Governing Knowledge Processes: Theoretical Foundations and Research Opportunities.

2003-2: Yves Doz, Nicolai J. Foss, Stefanie Lenway, Marjorie Lyles, Silvia Massini, Thomas P. Murtha and Torben Pedersen: Future Frontiers in International Management Research: Innovation, Knowledge Creation, and Change in Multinational Companies.

2003-3: Snejina Michailova and Kate Hutchings: The Impact of In-Groups and OutGroups on Knowledge Sharing in Russia and China CKG Working Paper.

2003-4: Nicolai J. Foss and Torben Pedersen : The MNC as a Knowledge Structure: The Roles of Knowledge Sources and Organizational Instruments in MNC Knowledge Management CKG Working Paper.

2003-5: Kirsten Foss, Nicolai J. Foss and Xosé H. Vázquez-Vicente: “Tying the Manager's Hands": How Firms Can Make Credible Commitments That Make Opportunistic Managerial Intervention Less Likely CKG Working Paper.

2003-6: Marjorie Lyles, Torben Pedersen and Bent Petersen: Knowledge Gaps: The Case of Knowledge about Foreign Entry.

2003-7: Kirsten Foss and Nicolai J. Foss: The Limits to Designed Orders: Authority under "Distributed Knowledge" CKG Working Paper.

2003-8: Jens Gammelgaard and Torben Pedersen: Internal versus External Knowledge Sourcing of Subsidiaries - An Organizational Trade-Off.

2003-9: Kate Hutchings and Snejina Michailova: Facilitating Knowledge Sharing in Russian and Chinese Subsidiaries: The Importance of Groups and Personal Networks Accepted for publication in Journal of Knowledge Management.

2003-10: Volker Mahnke, Torben Pedersen and Markus Verzin: The impact of knowledge management on MNC subsidiary performance: the role of absorptive capacity CKG Working Paper.

2003-11: Tomas Hellström and Kenneth Husted: Mapping Knowledge and Intellectual Capital in Academic Environments: A Focus Group Study Accepted for publication in Journal of Intellectual Capital CKG Working Paper.

2003-12: Nicolai J Foss: Cognition and Motivation in the Theory of the Firm: Interaction or "Never the Twain Shall Meet"? Accepted for publication in Journal des Economistes et des Etudes Humaines CKG Working Paper.

2003-13: Dana Minbaeva and Snejina Michailova: Knowledge transfer and expatriation practices in MNCs: The role of disseminative capacity.

2003-14: Christian Vintergaard and Kenneth Husted: Enhancing selective capacity through venture bases. 


\section{4}

2004-1: Nicolai J. Foss: Knowledge and Organization in the Theory of the Multinational Corporation: Some Foundational Issues

2004-2: Dana B. Minbaeva: HRM practices and MNC knowledge transfer

2004-3: Bo Bernhard Nielsen and Snejina Michailova: Toward a phase-model of global knowledge management systems in multinational corporations

2004-4: Kirsten Foss \& Nicolai J Foss: The Next Step in the Evolution of the RBV: Integration with Transaction Cost Economics

2004-5: Teppo Felin \& Nicolai J. Foss: Methodological Individualism and the Organizational Capabilities Approach

2004-6: Jens Gammelgaard, Kenneth Husted, Snejina Michailova: Knowledge-sharing Behavior and Post-acquisition Integration Failure

2004-7: Jens Gammelgaard: Multinational Exploration of Acquired R\&D Activities

2004-8: Christoph Dörrenbächer \& Jens Gammelgaard: Subsidiary Upgrading? Strategic Inertia in the Development of German-owned Subsidiaries in Hungary

2004-9: Kirsten Foss \& Nicolai J. Foss: Resources and Transaction Costs: How the Economics of Property Rights Furthers the Resource-based View

2004-10: Jens Gammelgaard \& Thomas Ritter: The Knowledge Retrieval Matrix: Codification and Personification as Separate Strategies

2004-11: Nicolai J. Foss \& Peter G. Klein: Entrepreneurship and the Economic Theory of the Firm: Any Gains from Trade?

2004-12: Akshey Gupta \& Snejina Michailova: Knowledge Sharing in Knowledge-Intensive Firms: Opportunities and Limitations of Knowledge Codification

2004-13: Snejina Michailova \& Kate Hutchings: Knowledge Sharing and National Culture: A Comparison Between China and Russia

\section{5}

2005-1: Keld Laursen \& Ammon Salter: My Precious - The Role of Appropriability Strategies in Shaping Innovative Performance

2005-2: Nicolai J. Foss \& Peter G. Klein: The Theory of the Firm and Its Critics: A Stocktaking and Assessment

2005-3: Lars Bo Jeppesen \& Lars Frederiksen: Why Firm-Established User Communities Work for Innovation: The Personal Attributes of Innovative Users in the Case of Computer-Controlled Music

2005-4: Dana B. Minbaeva: Negative Impact of Hrm Complementarity on Knowledge Transfer in Mncs

2005-5: Kirsten Foss, Nicolai J. Foss, Peter G. Klein \& Sandra K. Klein: Austrian Capital Theory and the Link Between Entrepreneurship and the Theory of the Firm 
2005-1: Nicolai J. Foss: The Knowledge Governance Approach

2005-2: Torben J. Andersen: Capital Structure, Environmental Dynamism, Innovation Strategy, and Strategic Risk Management

2005-3: Torben J. Andersen: A Strategic Risk Management Framework for Multinational Enterprise

2005-4: Peter Holdt Christensen: Facilitating Knowledge Sharing: A Conceptual Framework

2005-5 Kirsten Foss \& Nicolai J. Foss: Hands Off! How Organizational Design Can Make Delegation Credible

2005-6 Marjorie A. Lyles, Torben Pedersen \& Bent Petersen: Closing the Knowledge Gap in Foreign Markets - A Learning Perspective

2005-7 Christian Geisler Asmussen, Torben Pedersen \& Bent Petersen: How do we capture "Global Specialization" when measuring firms' degree of internationalization?

2005-8 Kirsten Foss \& Nicolai J. Foss: Simon on Problem-Solving: Implications for New Organizational Forms

2005-9 Birgitte Grøgaard, Carmine Gioia \& Gabriel R.G. Benito: An Empirical Investigation of the Role of Industry Factors in the Internationalization Patterns of Firms

2005-10 Torben J. Andersen: The Performance and Risk Management Implications of Multinationality: An Industry Perspective

2005-11 Nicolai J. Foss: The Scientific Progress in Strategic Management: The case of the Resource-based view

2005-12 Koen H. Heimeriks: Alliance capability as a mediator between experience and alliance performance: An empirical investigation into the alliance capability development process

2005-13 Koen H. Heimeriks, Geert Duysters \& Wim Vanhaverbeke: Developing Alliance Capabilities: An Empirical Study

2005-14 JC Spender: Management, Rational or Creative? A Knowledge-Based Discussion

\section{6}

2006-1: Nicolai J. Foss \& Peter G. Klein: The Emergence of the Modern Theory of the Firm

2006-2: Teppo Felin \& Nicolai J. Foss: Individuals and Organizations: Thoughts on a Micro-Foundations Project for Strategic Management and Organizational Analysis

2006-3: Volker Mahnke, Torben Pedersen \& Markus Venzin: Does Knowledge Sharing Pay? An MNC Subsidiary Perspective on Knowledge Outflows

2006-4: Torben Pedersen: Determining Factors of Subsidiary Development 
2006-5 Ibuki Ishikawa: The source of competitive advantage and entrepreneurial judgment in the RBV: Insights from the Austrian school perspective

2006-6 Nicolai J. Foss \& Ibuki Ishikawa: Towards a dynamic resource-based view: Insights from Austrian capital and entrepreneurship theory

2006-7 Kirsten Foss \& Nicolai J. Foss: Entrepreneurship, Transaction Costs, and Resource Attributes

2006-8 Kirsten Foss, Nicolai J. Foss \& Peter G. Klein: Original and Derived Judgement: An Entrepreneurial Theory of Economic Organization

2006-9 Mia Reinholt: No More Polarization, Please! Towards a More Nuanced Perspective on Motivation in Organizations

2006-10 Angelika Lindstrand, Sara Melen \& Emilia Rovira: Turning social capital into business? A study of Swedish biotech firms' international expansion

2006-11 Christian Geisler Asmussen, Torben Pedersen \& Charles Dhanaraj: Evolution of Subsidiary Competences: Extending the Diamond Network Model

2006-12 John Holt, William R. Purcell, Sidney J. Gray \& Torben Pedersen: Decision Factors Influencing MNEs Regional Headquarters Location Selection Strategies

2006-13 Peter Maskell, Torben Pedersen, Bent Petersen \& Jens Dick-Nielsen: Learning Paths to Offshore Outsourcing - From Cost Reduction to Knowledge Seeking

2006-14 Christian Geisler Asmussen: Local, Regional or Global? Quantifying MNC Geographic Scope

2006-15 Christian Bjørnskov \& Nicolai J. Foss: Economic Freedom and Entrepreneurial Activity: SOME CROSS-COUNTRY EVIDENCE

2006-16 Nicolai J. Foss \& Giampaolo Garzarelli: Institutions as Knowledge Capital: Ludwig M. Lachmann's Interpretative Institutionalism

2006-17 Koen H. Heimriks \& Jeffrey J. Reuer: How to build alliance capabilities

2006-18 Nicolai J. Foss, Peter G. Klein, Yasemin Y. Kor \& Joseph T. Mahoney: Entrepreneurship, Subjectivism, and the Resource - Based view: Towards a new synthesis 